\title{
NILAI TAMBAH MINYAK AKAR WANGI DENGAN PEMEKATAN KADAR VETIVEROL MENGGUNAKAN EKSTRAKSI $\mathrm{CO}_{2}$ FLUIDA SUPERKRITIK
}

\author{
VETIVER OIL VALUE ADDED WITH CONCENTRATION VETIVEROL CONTENT \\ BY USING $\mathrm{CO}_{2}$ SUPERCRITICAL FLUID EXTRACTION
}

\author{
Anny Sulaswatty dan Egi Agustian \\ Pusat Penelitian Kimia -LIPI \\ Kawasan PUSPIPTEK Serpong, Tangerang Selatan Banten 15314 \\ Email: anny001@lipi.go.id
}

Diterima : 27 Juli 2014, Revisi : 08 Juli 2014, Disetujui : 18 Juli 2014

\begin{abstract}
ABSTRAK
Potensi Indonesia akan minyak akar wangi yang berorientasi ekspor dalam industri kosmetik, parfum, sabun, keperluan terapi, antiseptik, massage oil, farmasi dan pestisida memberikan peluang yang besar untuk memenuhi kebutuhan dunia. Guna nilai tambah minyak akar wangi dengan meningkatkan kadar vetiverol sebagai komponen utama, diaplikasikan teknologi ekstraksi fluida karbondioksida superkritik yang merupakan perpaduan ekstraksi, fraksinasi dan deodorisasi dengan didukung keunggulan karbondioksida sebagai pelarut yang inert, ramah lingkungan, mudah dipisahkan, dan berdaya larut tinggi. Minyak akar wangi Garut (Java vetiver oil) sebagai bahan baku, mempunyai karakteristik kadar vetiverol 39.03 $\%$,Bobot jenis 0.9977 ; indeks bias 1.5247 ; putaran optik +38.1 ; kelarutan dalam alkohol $95 \%$ yaitu $1: 1$ jernih; bilangan asam 28,1 ; bilangan ester 24,6 ; bilangan ester setelah asetilasi 115,5 ; serta tidak mengandung minyak lemak dan minyak keruing. Pemilihan kondisi proses guna menghasilkan kandungan vetiverol optimal dilakukan dengan memvariasikan laju alir gas $\mathrm{CO}_{2}$, tekanan dan suhu sebagai parameter penting dalam keberhasilan proses ekstraksi minyak akar wangi dengan fluida $\mathrm{CO}_{2}$ superkritik. Pemilihan laju alir konstan dan lebih stabil diperoleh pada 5.5 liter/menit, sedangkan untuk variasi tekanan ekstraktor $(1500,1750,2000 \mathrm{psi})$ dan suhu ekstraktor $\left(40-50^{\circ} \mathrm{C}\right)$; tekanan dan suhu separator $500 \mathrm{psi}$ dan $25^{\circ} \mathrm{C}$ serta waktu proses selama lima jam dengan pengambilan ekstrak setiap jam. Tekanan dan suhu proses yang optimal diperoleh pada $1750 \mathrm{psi}$ dan suhu $40^{\circ} \mathrm{C}$ dengan rafinat minyak akar wangi berkadar vetiverol $51.82 \%$, bilangan ester 7.16 dan bilangan ester setelah asetilasi 172,4 . Tingginya tekanan dan rendahnya suhu berpengaruh terhadap perolehan ekstrak; penurunan rafinat; peningkatan nilai bobot jenis ekstrak dan rafinat; indeks bias ekstrak dan rafinat; putaran optik ekstrak dan rafinat; peningkatan viskositas ekstrak dan rafinat; peningkatan bilangan ester ekstrak, bilangan ester setelah asetilasi ekstrak, serta kandungan vetiverol.
\end{abstract}

Kata kunci : Minyak Akar Wangi, Vetiverol, Ekstraksi Fluida Superkritik.

\begin{abstract}
Potential Indonesian vetiver oil export oriented industry of cosmetics, perfumes, soaps, therapeutic purposes, antiseptic, massage oil, pharmaceutical and pesticide presents a great opportunity to meet the needs of the world. In order to add value vetiver oil by increasing the levels vetiverol as the main component, was applied to carbon dioxide supercritical fluid extraction technology which is a combination of extraction, fractionation and deodorization with excellence supported carbon dioxide as an inert solvent, eco-friendly, easily separated, and the high solubility. Garut vetiver oil (Java vetiver oil) as raw material, has the characteristics vetiverol levels $39.03 \%$, specific gravity of 0.9977 ; refractive index of 1.5247; optical rotation +38.1 ; solubility in alcohol $95 \%$ is a clear 1:1; acid number 28.2; ester number 24.6; ester number after acetylation 115.5; as well as fats and oils contain no oil keruing. The selection process conditions in order to produce optimal vetiverol content performed by varying the flow rate of $\mathrm{CO}_{2}$ gas, pressure and temperature as an important parameter in the success of vetiver oil extraction with supercritical $\mathrm{CO}_{2}$ fluid. The selection of a constant flow rate and more stable obtained at 5.5 liters / min, whereas for pressure variation extractor (1500-2000 psi) and extractor temperature $\left(40-50^{\circ} \mathrm{C}\right)$; separator pressure and temperature of 500 psi and $25^{\circ} \mathrm{C}$ as well as the processing time for five hours by taking extracts every hour. Pressure and temperature optimum process obtained at $1750 \mathrm{psi}$ and a temperature of $40^{\circ} \mathrm{C}$ with rafinat vetiverol vetiver oil yield of $51.82 \%$, ester number 7.16 , and ester number after acetylation 172.4. The high pressure and low temperature affect the acquisition of the extract; rafinat decline; increase in the value of specific gravity and rafinat extracts; refractive index and rafinat extract; optical rotation and rafinat extract; increase in the viscosity of the extract and rafinat; increase in numbers ester extract, ester number after acetylation extracts, as well as the content vetiverol.
\end{abstract}

Keywords: Vetiver Oil, Vetiverol, Supercritical Fluid Extraction 


\section{PENDAHULUAN}

Minyak akar wangi (vetiver oil) adalah produk agroindustri yang berorientasi ekspor dengan kandungan lokal yang sangat tinggi dan berpeluang untuk dikembangkan menjadi komoditi ekspor unggulan Indonesia. Minyak akar wangi mempunyai nilai ekonomi yang tinggi disebabkan sifatnya yang khas seperti bau yang kuat, daya penguapan rendah dan daya fiksasinya kuat. Umumnya minyak akar wangi digunakan dalam industri kosmetik, parfum, sabun, keperluan terapi, anti septik, massage oil, pestisida dan aromatherapy ${ }^{(1)}$.

Kebutuhan dunia terhadap minyak akar wangi hampir mencapai 250 ton/tahun. Tujuan pasar utama adalah negara-negara di Asia, Eropa Timur, Amerika Serikat dan Amerika Selatan. Indonesia sementara ini hanya mampu memenuhi 48 ton setahun sedangkan Haiti sebanyak 100 ton dan sisanya dipasok oleh Cina dan Rumania ${ }^{(2)}$.

Komponen kimia minyak akar wangi terdiri dari vetiverol, vetivon, khusilal, khusinol, khusimol, khusol dan asam benzoat $t^{(3)}$. Vetiverol yang terdapat dalam minyak akar wangi sekitar $45-65 \%$, mempengaruhi bilangan ester setelah asetilasi, merupakan seskuiterpen alkohol bebas, titik didih $\left(265.5-282^{\circ} \mathrm{C}\right)$, campuran alkohol primer $\left(\mathrm{C}_{15} \mathrm{H}_{24} \mathrm{O}\right)$ sekitar $60 \%$ alkohol trisiklik dan $10 \%$ alkohol bisiklik, sisanya alkohol bisiklik tersier. Minyak akar wangi yang diperbolehkan untuk perdagangan harus sesuai dengan standar yang ditentukan yaitu SNI 06-2386-2006. Minyak atsiri yang diperoleh dari hasil ekstraksi konvensional (intermediate crude atsiri) sebagian tidak dapat digunakan secara langsung. Pengolahan lanjut minyak atsiri seperti proses pemurnian, pemisahan dan sintesis, merupakan salah satu cara untuk meningkatkan komponen-komponen dalam minyak atsiri. Komposisi atau kandungan masing-masing komponen kimia minyak atsiri merupakan hal yang paling mendasar dan sangat penting dalam menentukan aroma, kualitas maupun kegunaannya sebagai bahan pengharum, kosmetik, obat dan lain-lain ${ }^{(4)}$.

Salah satu pengolahan lanjut untuk meningkatkan komponen dalam minyak atsiri adalah dengan ekstraksi fluida karbondioksida superkritik (SFE). Metode ini berkembang pada dekade terakhir $( \pm 1900)$ yang menggunakan prinsip pemisahan komponen pada kondisi tekanan dan suhu di atas titik kritis. Cara ini tidak merusak bahan yang sensitif panas atau termolabil karena ekstraksi dilakukan pada suhu rendah $^{(3)}$. Metode ini merupakan perpaduan proses ekstraksi, deodorisasi dan fraksinasi yang didukung dengan karbondioksida sebagai pelarut yang ramah terhadap lingkungan, tidak berbahaya, tidak mudah terbakar, relatif murah dan memiliki daya larut yang lebih baik dibandingkan dengan pelarut organik konvensional lainnya ${ }^{(\text {) }}$. Ekstraksi fluida superkritik adalah suatu unit operasi baru yang memanfaatkan sifatsifat unik dari pelarut di atas titik kritisnya untuk mengekstrak komponen-komponen dari suatu campuran ${ }^{(\pi)}$. Teknik ekstraksi dengan fluida superkritik (Supercritical Fluid Extraction) adalah teknik pemisahan yang memanfaatkan daya pelarut dari fluida superkritik pada suhu dan tekanan disekitar titik kritis. Tekanan dan Temperatur yang digunakan dalam ekstraksi merupakan parameter utama dalam menentukan besarnya daya larut ${ }^{(s)}$. Beberapa peneliti menggunakan superkritik $\mathrm{CO}_{2}$ untuk ekstraksi teh hijau, menurut Wang et al, SFE dapat mengekstrak akar ginseng dan terbukti meningkatkan rendemen ${ }^{(9)}$, sedangkan Badalyan mengekstraksi jahe oleoresin menggunakan etanol sebagai co-solvent dengan metode $\mathrm{SFE}^{(10)}$. Sedangkan menurut Talansier et al (2008), SFE dapat meningkatkan rendemen vetiver root sebesar 14$29 \%$ dibandingkan hydrodistilasi ${ }^{(11)}$. Dari beberapa literature diatas bahwa SFE dapat meningkatkan rendemen ekstrak dibandingkan ekstraksi yang konvensional.

Maka penelitian ini bertujuan untuk mempelajari pemisahan komponen minyak akar wangi menggunakan ekstraksi superkritik $\mathrm{CO}_{2}$ khususnya peningkatan kandungan vetiverol dan mencari kondisi optimum ekstraksi superkritik.

\section{BAHAN DAN METODA}

\section{Bahan}

Bahan baku yang digunakan dalam penelitian ini adalah minyak akar wangi kasar (crude vetiver oil) yang berasal dari petani penyulingan di Kabupaten Garut, Indonesia. Selain itu bahan kimia yang digunakan untuk proses adalah gas karbondioksida (teknis), etanol teknis, asam sulfat (p.a), potassium hidroksida (p.a) dan bahan penunjang lain seperti es batu dan alat gelas lainnya. Bahan baku dan hasil dari proses ekstraksi fluida superkritik akan dianalisa sifat fisiko kimianya.

\section{Peralatan}

Alat utama dalam proses pemisahan komponen minyak akar wangi adalah satu unit Supercritical Fluid Extraction Model 46-19360 (Gambar 1) dari Superpressure Newport Scientific Inc, USA yang berada di Pusat Penelitian Kimia-LIPI, Serpong. 


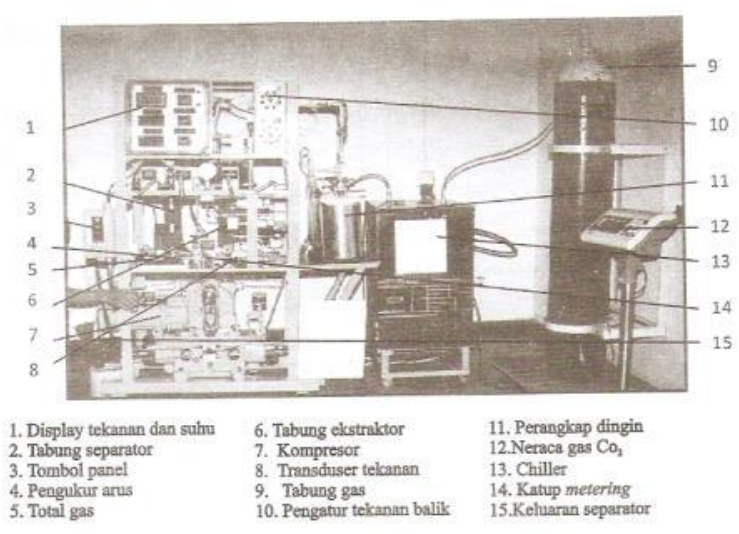

Gambar 1. Unit Ekstraksi Fluida $\mathrm{CO}_{2}$ Superkritik

\section{Metoda Penelitian}

Penelitian ini diawali dengan penetapan laju alir gas karbondioksida dan dilanjutkan dengan memvariasikan tekanan serta suhu di ekstraktor untuk mencari kondisi proses optimal yang menghasilkan minyak akar wangi dengan kandungan vetiverol tertinggi. Kondisi proses yang digunakan dalam penetapan laju alir adalah tekanan dan suhu ekstraktor yaitu 1500 psi dan $40^{\circ} \mathrm{C}$ dengan laju alir sebesar $5.5-6.0$ liter/menit.

Proses ekstraksi komponen minyak akar wangi dengan beberapa variasi tekanan $(1500,1750,2000 \mathrm{psi})$ dan suhu ekstraktor $\left(40-50^{\circ} \mathrm{C}\right)$ pada laju alir yang ditetapkan pada penelitian pendahuluan. Tekanan dan suhu separator menjadi konstanta tetap $\left(500 \mathrm{psi}, 40^{\circ} \mathrm{C}\right)$, selama 5 Jam. Setiap jam diambil sampling untuk dianalisa.

Proses pemisahan komponen minyak akar wangi dengan ekstraksi fluida karbondioksida superkritik terdiri dari tiga tahap yaitu tahap persiapan, tahap proses dan tahap flushing. Analisa sifat fisik mencakup bobot jenis, indeks bias, putaran optik, warna, viskositas, kelarutan dalam alkohol dan minyak lemak/minyak keruing, sedangkan analisa sifat kimia minyak akar wangi meliputi bilangan asam, bilangan ester, bilangan ester setelah asetilasi, kadar vetiverol.

\section{HASIL DAN PEMBAHASAN}

Karakteristik minyak akar wangi Garut sebagai bahan baku proses ekstraksi komponen secara keseluruhan sesuai dengan standar mutu yang ditetapkan (SNI, 2006) dengan nilai bobot jenis 0.9781.038 , indeks bias 1.5247 . Derajat rotasi +38.1 , warna coklat kemerahan. Intensitas warna skala Lovibond Kuning: Merah: Biru =21.2: 6.2: 0.3. Dimana warna pembentuk minyak akar wangi adalah kuning (Sirendra dan Sulaswatty, 2003), Viskositas $107.5 \mathrm{cp}$; bilangan asam 28.11 , bilangan ester 24.56 ; sedangkan minyak lemak dan minyak keruing, diperoleh negatif. Perhitungan bilangan ester setelah asetilasi sebesar 115.49 serta Kadar vetiverol sebesar $39.03 \%$. Kandungan vetiverol pada bahan baku relatif rendah dari batas minimal standar $39-59 \%{ }^{(12)}$.

\section{Penetapan LajuAlir Karbondioksida}

Kriteria proses yang memiliki pengaruh besar terhadap keberhasilan desain proses adalah laju alir karbondioksida (Laili et al., 2003) ${ }^{(13)}$. Penetapan nilai laju alir yang konstan untuk proses pemisahan komponen minyak akar wangi adalah dengan membandingkan laju alir antara 5.5-6.0 liter/menit dilakukan pada tekanan dan suhu ekstraktor sebesar 1500 psi dan $40^{\circ} \mathrm{C}$ selama 255 menit. Laju alir sebesar 5.5 liter/menit merupakan laju alir yang terpilih untuk proses pemisahan komponen. Laju alir ini selama proses lebih stabil dalam kisaran 5.5 liter/menit dan proses pengendalian laju alir lebih mudah sehingga kestabilan laju alir dapat dikontrol dengan baik.

\section{Pemisahan Komponen Minyak Akar Wangi dengan Ekstraksi Fluida Karbondioksida Superkritik}

Untuk dapat mengekstrak komponen secara sempurna diperlukan pengaturan tekanan dan suhu operasi maksimum. Tercapainya suhu ini sangat tergantung pada sifat fisik dan kimia substrat, sedangkan tekanan maksimum tergantung pada perancangan peralatan. Kondisi proses yang dipilih untuk proses pemisahan komponen minyak akar wangi melibatkan variasi tekanan dan suhu pada tabung ekstraktor yaitu sebesar 1500 - 2000 psi dengan suhu 40$50^{\circ} \mathrm{C}$, serta waktu proses selama 5 jam. Kondisi proses konstan selain laju alir adalah tekanan dan suhu pada bejana separator yaitu $500 \mathrm{psi}$ dan $25^{\circ} \mathrm{C}$. Pemilihan batas terendah tekanan $1500 \mathrm{psi}$ dan temperatur $40^{\circ} \mathrm{C}$ didasari titik kritis pelarut yaitu karbondioksida, suhu kritis dan tekanan kritis karbondioksida adalah $31^{\circ} \mathrm{C}$ dan 73 bar (1072.8 psi) (Arai et al., 2002; Rizvi, 1999) ${ }^{(7,14)}$.

\section{Pengaruh Waktu Proses terhadap Ekstrak dan Rendemen}

Proses pemisahan komponen minyak akar wangi menghasilkan dua produk yang terdiri dari ekstrak dan rafinat. Bagian ekstrak, lebih didominasi oleh komponen berfraksi ringan. Sedangkan bagian rafinat terdiri dari fraksi berat. Lamanya waktu proses mempengaruhi jumlah ekstrak maupun rafinat yang dihasilkan. Pengambilan ekstrak dilakukan setiap 1 jam proses dan hasilnya dapat dilihat pada Gambar 2. 

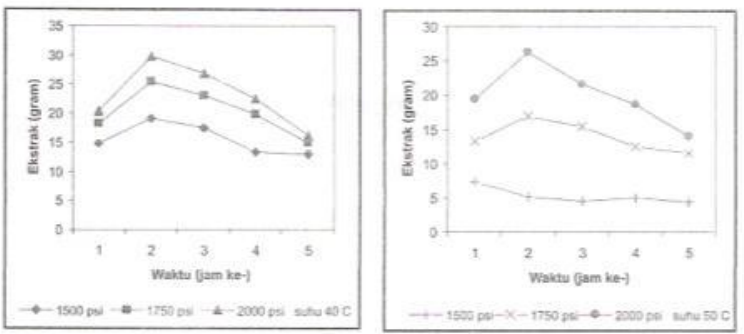

Gambar 2. Hubungan Waktu Proses terhadap Ekstrak Minyak Akar Wangi pada Laju Alir $\mathrm{CO}_{2} 5.5$ liter/menit dan Umpan \pm 200 gram. Dimana $A=\operatorname{suhu} 40^{\circ} \mathrm{C}$ dan $B=\operatorname{suhu} 50^{\circ} \mathrm{C}$

Pada Gambar 2A dan 2B dapat dilihat perolehan jumlah ekstrak pada proses pemisahan komponen minyak akar wangi umumnya cenderung mengalami peningkatan namun semakin lama waktu proses maka jumlah bahan awal akan semakin berkurang dan adanya tingkat kejenuhan dari karbondioksida dalam mengekstraksi komponen minyak akar wangi. Kemampuan sistem dalam mempertahankan keadaan yang stabil dalam kondisi ini tidak optimal sehingga menurunkan daya larut dari karbondioksida. Tingginya suhu dan rendahnya tekanan mengakibatkan molekulmolekul karbondioksida bergerak acak dan cepat sehingga kontak dengan minyak tidak sempurna. Berdasarkan sifatnya sebagai pengikat, komponen minyak akar wangi yang memiliki bobot molekul yang tinggi tidak dapat terdorong ke dalam ekstrak.

Kecuali pada Gambar 2B dimana kondisi tekanan $1500 \mathrm{psi}$ dan suhu $50^{\circ} \mathrm{C}$, memiliki kecenderungan pola yang berbeda. Jam ke-1 menghasilkan jumlah ekstrak tertinggi yaitu 7.38 gram. Mulai jam ke-2 sampai jam ke-5 dimana jumlah ekstrak semakin berkurang, yaitu 5.09 gram; 4.59 gram; 5.00 gram; dan 4.33 gram. Kondisi proses 1500 psi dan suhu $50^{\circ} \mathrm{C}$ disamping menunjukkan pola yang berbeda dengan kondisi proses lainnya juga menghasilkan ekstrak yang terkecil. Kemampuan sistem dalam mempertahankan keadaan yang stabil dalam kondisi ini tidak optimal sehingga menurunkan daya larut dari karbondioksida.

Dalam penelitian ini, pengaruh tingginya tekanan dan rendahnya suhu menyebabkan daya selektifitas pelarut terhadap solut semakin berkurang. Artinya, kemampuan pelarut untuk melarutkan berbagai komponen yang terkandung dalam bahan baku lebih mudah dilakukan.

Perubahan rendemen seiring dengan perubahan waktu ekstraksi, pada umumnya mengalami peningkatan pada jam ke-2 dan ke-4. Seiring dengan peningkatan jumlah ekstrak, tingkat rendemen pada jam kedua mengalami peningkatan. Hal ini akibat dari daya solubilitas karbondioksida yang mulai bekerja secara optimal terhadap minyak akar wangi. Kecenderungan ini dapat terlihat pada Gambar 3.
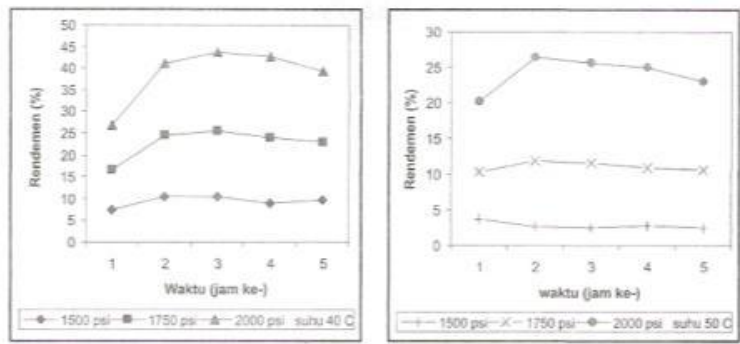

Gambar 3. Pengaruh Lama Waktu Proses Pemekatan terhadap Rendemen Minyak Akar Wangi dengan Ekstraksi Fluida CO2 Superkritik pada Laju Alir $\mathrm{CO}_{2} 5.5$ liter/menit dan Umpan \pm 200 gram. Dimana $\mathrm{A}=40^{\circ} \mathrm{C}$ dan $\mathrm{B}=50^{\circ} \mathrm{C}$

Gambar 3A terlihat berbeda dengan kondisi lain, dimana tekanan 1500 psi dan suhu $50^{\circ} \mathrm{C}$ justru mengalami penurunan pada jam ke-2 namun terjadi sedikit peningkatan pada jam ke-4. Hal ini disebabkan kemampuan gas $\mathrm{CO}_{2}$ pada kondisi tidak dapat melarutkan dengan sempurna sehingga tingkat rendemen minyak akar wangi menurun.

Perubahan tekanan yang semakin tinggi menyebabkan persentase rendemen semakin meningkat. Kenaikan tekanan akan memampatkan gas sehingga volumenya mengecil sekaligus memperbesar densitas. Meningkatnya densitas karbondioksida menyebabkan jarak antar molekul semakin dekat sehingga jarak tempuh perpindahan massa dari solut ke solven secara difusi semakin mengecil dan kecepatan pelarutan semakin besar. Tekanan 2000 psi dan suhu $50^{\circ} \mathrm{C}$ menghasilkan rendemen terbesar $14.64 \%$; sedang pada Suhu $40^{\circ} \mathrm{C}$ cenderung memiliki tingkat persentase rendemen yang lebih tinggi dibandingkan dengan suhu $50^{\circ} \mathrm{C}$. Pengaruh suhu berlawanan dengan pengaruh tekanan. Kenaikan suhu akan memuaikan gas, memperbesar volume gas dan memperkecil densitas gas tersebut. Fenomena yang sama terjadi pada tekanan $1750 \mathrm{psi}$, pada suhu yang lebih rendah tingkat rendemen yang dihasilkan justru lebih tinggi. Pada suhu $40^{\circ} \mathrm{C}$, persentase rendemen tertinggi $15.04 \%$.

\section{Pengaruh Tekanan terhadap Kandungan Vetiverol}

Berdasarkan adanya kebutuhan minyak akar wangi dengan komponen vetiverol yang tinggi, produk yang paling utama dari proses ini adalah rafinat yaitu bagian yang tertinggal didalam tabung ekstraktor pada proses ekstraksi fluida superkritik. Rafinat merupakan hasil yang diharapkan dari proses karena dalam rafinat didominasi oleh fraksi berat yang dibutuhkan sebagai zat fixative (pengikat) dalam industri parfum. Vetiverol 
termasuk golongan hidrokarbon-O dalam minyak akar wangi. Jumlah vetiverol dapat ditentukan dengan proses ester setelah asetilasi yang melibatkan bilangan ester dengan bilangan ester setelah asetilasi. Pengaruh tekanan terhadap kandungan total vetiverol dapat terlihat pada Gambar 4.

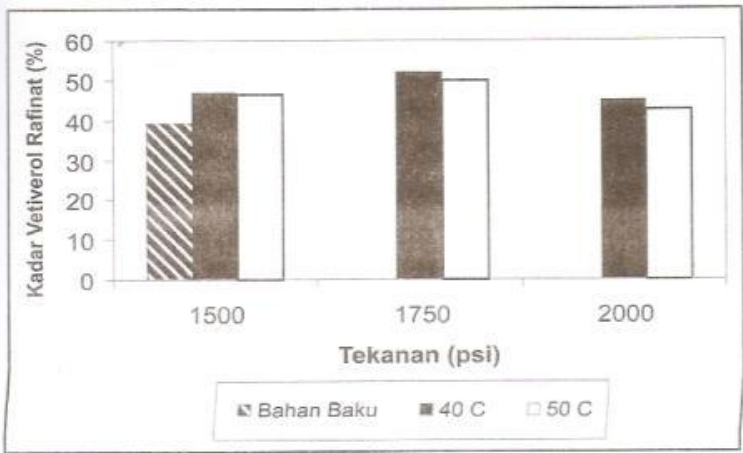

Gambar 4. Pengaruh Tekanan terhadapt kandungan Total Vetiverol Rafinat Minyak Akar Wangi

Menurut SNI 06-2386, batas maksimal kadar vetiverol dalam minyak akar wangi adalah 59 persen, dengan ekstraksi fluida karbondioksida superkritik sudah dapat meningkatkan kadar total vetiverol dari bahan baku sebesar $39.03 \%$ ke $51.82 \%$ pada tekanan $1750 \mathrm{psi}$ dan suhu $40^{\circ} \mathrm{C}$ (Gambar 4). Meskipun belum sampai batas tertinggi sesuai standar, peningkatan kadar total vetiverol ini menunjukkan adanya peningkatan mutu dari minyak akar wangi yang signifikan.

\section{Karakteristik Fisiko Kimia Rafinat Minyak Akar Wangi}

Berdasarkan kondisi proses ekstraksi menggunakan pelarut fluida superkritik yang bersifat inert, maka peristiwa ekstraksi merupakan peristiwa perubahan fisik dan tidak terjadi peristiwa kimiawi, artinya bentuk dasar komponen masing-masing tetap karena tidak ada reaksi kimia. Peristiwa yang terjadi dalam proses ekstraksi adalah perpindahan masa dari satu pelarut ke pelarut lain yang tergantung dari kelarutan solut dalam pelarut dan selektifitas pelarut ${ }^{(15)}$.

Karakteristik ekstrak minyak akar wangi dari proses pemisahan komponen dengan ekstraksi fluida superkritik pada umumnya lebih rendah dibandingkan dengan nilai karakteristik bahan baku. Hal ini disebabkan komponen utama penyusun dari ekstrak didominasi oleh fraksi ringan. Komponen tersebut mudah didorong oleh pelarut karbondioksida akibat adanya pengaruh tekanan dan suhu proses. Hasil analisa sifat fisiko kimia dari ekstrak minyak akar wangi ditunjukkan pada Tabel 1.
Tabel 1. Karakteristik Sifat Fisiko Kimia Ekstrak Minyak AkarWangi

\begin{tabular}{|c|c|c|c|c|c|c|c|c|}
\hline \multirow{3}{*}{\multicolumn{2}{|c|}{ Parameter Analisa }} & \multirow{3}{*}{$\begin{array}{l}\text { Baban } \\
\text { Bakm }\end{array}$} & \multicolumn{6}{|c|}{ Elstrak } \\
\hline & & & \multicolumn{3}{|c|}{$40^{\circ} \mathrm{C}$} & \multicolumn{3}{|c|}{$50^{\circ} \mathrm{C}$} \\
\hline & & & $1500 \mathrm{psi}$ & $1750 \mathrm{psi}$ & 2000 pri & $1590 \mathrm{psi}$ & 1750 psi & $2009 \mathrm{psi}$ \\
\hline \multicolumn{2}{|c|}{ Kadar Vetiverol (\%) } & 39.03 & 1.93 & 2.20 & 2.34 & 1.66 & 206 & 2.34 \\
\hline \multicolumn{2}{|c|}{ Bobot Jenis (g/mi) } & 0.9977 & 0.9688 & 0.972 & 0.9774 & 0.9665 & 0.9706 & 0.9731 \\
\hline \multicolumn{2}{|c|}{ Indeks bias $\left(20^{\circ} \mathrm{C}\right)$} & 1.5247 & 15190 & 1.5197 & 1.5211 & 1.5189 & 1.5196 & 1.5202 \\
\hline \multicolumn{2}{|l|}{ Putaran Optik } & 38.1 & 12.81 & 15.45 & 16.19 & 11.28 & 13.9 & 15.82 \\
\hline \multicolumn{2}{|l|}{ Wama } & $\begin{array}{c}\text { collat } \\
\text { kemererhan }\end{array}$ & $\begin{array}{l}\text { kuning } \\
\text { muda }\end{array}$ & $\begin{array}{l}\text { kuning } \\
\text { moda }\end{array}$ & $\begin{array}{l}\text { huning } \\
\text { mode }\end{array}$ & $\begin{array}{l}\text { haning } \\
\text { mude }\end{array}$ & $\begin{array}{l}\text { baning } \\
\text { mode }\end{array}$ & $\begin{array}{l}\text { kuing } \\
\text { moda }\end{array}$ \\
\hline \multirow[t]{4}{*}{ Lovibood } & merah & 6.2 & 0.3 & 0.3 & 0.3 & 0.5 & 0.4 & 0.3 \\
\hline & huning & 21.2 & 3.3 & 3.3 & 3.4 & 3.5 & 3.35 & 3.4 \\
\hline & binu & 0.3 & 0 & 0 & 0 & 0 & 0 & 0 \\
\hline & putili & 0 & 0 & 0 & 0 & 0 & 0 & 0 \\
\hline \multicolumn{2}{|l|}{ Viskositas (CP) } & 107.50 & 9.54 & 13.61 & 18.41 & 9.21 & 1099 & 14.39 \\
\hline \multicolumn{2}{|l|}{ Bilangan Asam } & 28.1 & 5.3 & 8.7 & 9.9 & 7.6 & 93 & 109 \\
\hline \multicolumn{2}{|l|}{ Bilangan Ester } & 24.6 & 11.6 & 13.6 & 17.1 & 9.3 & 12.7 & 15.3 \\
\hline \multicolumn{2}{|c|}{$\begin{array}{l}\text { Billangan Ester setelah } \\
\text { Asetilasi }\end{array}$} & 115.5 & 163 & 19.1 & 22.9 & 13.5 & 17.7 & 21.2 \\
\hline \multicolumn{2}{|c|}{$\begin{array}{l}\text { Minyak Lemak \& } \\
\text { Minyak Keruing }\end{array}$} & Negative & Negative & negatif & negatif & negatif & aegaif & Negative \\
\hline \multicolumn{2}{|l|}{$\begin{array}{l}\text { Kelarutan dalam } \\
\text { Allkohol } 95 \%\end{array}$} & \multicolumn{7}{|c|}{ 1:1 jemih den seterusuya jernih } \\
\hline
\end{tabular}

Pada Tabel 2 dapat dilihat bahawa karakteristik sifat fisiko kimia rafinat minyak akar wangi lebih tinggi dibandingkan dengan bahan baku maupun ekstrak. Komponen utama minyak yang menyebabkan harga jual minyak akar wangi di pasaran menjadi tinggi adalah kandungan vetiverol. Perhitungan kadar total vetiverol dari suatu minyak akar wangi tidak terlepas dari analisa bilangan ester setelah asetilasi dengan bilangan ester. Kadar vetiverol merupakan kadar komponenkomponen beralkohol dalam minyak akar wangi yang tergolong pada sesquiterpen alkohol bebas (sesquiterphenol). Minyak yang bermutu baik umumnya mengandung vetiverol diatas $50 \%$.

Tabel 2. Karakteristik Sifat Fisiko Kimia Rafinat Minyak Akar Wangi

\begin{tabular}{|c|c|c|c|c|c|c|c|c|}
\hline \multirow{3}{*}{\multicolumn{2}{|c|}{ Parameter Amalilea }} & \multirow{3}{*}{$\begin{array}{l}\text { Bahnan } \\
\text { Baku }\end{array}$} & \multicolumn{6}{|c|}{ Rufinat } \\
\hline & & & \multicolumn{3}{|c|}{$40^{\circ} \mathrm{C}$} & \multicolumn{3}{|c|}{$50^{\circ} \mathrm{C}$} \\
\hline & & & $1500 \mathrm{psi}$ & $1750 \mathrm{peli}$ & 2000 pil & $1500 \mathrm{psi}$ & 1750 pd & $2000 \mathrm{pd}$ \\
\hline \multicolumn{2}{|c|}{ Kadar Vetiverol (\%) } & 39.03 & 47.03 & 51.82 & 44.76 & 46.61 & 49.85 & 42,45 \\
\hline \multicolumn{2}{|c|}{ Bobot Jenis (g/mi) } & 0.9977 & 1.0210 & 1.0578 & 1.0653 & 1.0068 & 1.0238 & 1.0602 \\
\hline \multicolumn{2}{|c|}{ Indeks bias $\left(20^{\circ} \mathrm{C}\right)$} & 1.5247 & 1.5275 & 1.5295 & 1.5305 & 1.5266 & 1.5285 & 1.5297 \\
\hline \multicolumn{2}{|c|}{ Putann Optik } & 38.1 & 45.45 & 49.45 & 53.00 & 40.45 & 48.55 & 52.75 \\
\hline \multicolumn{2}{|l|}{ Wame } & $\begin{array}{c}\text { coldist } \\
\text { kemerahan }\end{array}$ & $\begin{array}{c}\text { coklat } \\
\text { kemuerahan }\end{array}$ & $\begin{array}{c}\text { collat } \\
\text { kemerahan }\end{array}$ & $\begin{array}{c}\text { colkht } \\
\text { kehituman }\end{array}$ & $\begin{array}{c}\text { colkiat } \\
\text { kementhan }\end{array}$ & $\begin{array}{c}\text { Colkat } \\
\text { kehitaman }\end{array}$ & $\begin{array}{c}\text { coklat } \\
\text { kethitamas }\end{array}$ \\
\hline \multirow[t]{4}{*}{ Lovibond: } & mereh & 6.2 & 11.1 & 14.05 & 17 & 735 & 10.5 & 13.85 \\
\hline & haning & 21.2 & 25.65 & 22.75 & 27.1 & 31.55 & 23.5 & 22 \\
\hline & biru & 0.3 & 0.25 & 1.1 & 0.5 & 0 & 1.1 & 1.55 \\
\hline & puth & 0 & 0 & 0 & 0 & 0 & 0 & 0 \\
\hline \multicolumn{2}{|c|}{ Viskositas (CP) } & 107.50 & 1156.22 & 2238.64 & 7486.10 & 199.26 & 1429.92 & 5363.34 \\
\hline \multicolumn{2}{|c|}{ Bilangan Asem } & 28.1 & 31.7 & 33.7 & 35.6 & 32.2 & 34.8 & 37.1 \\
\hline \multicolumn{2}{|c|}{ Bilangan Ester } & 24.6 & 43.6 & 572 & 42.1 & 40.8 & 47.5 & 40.3 \\
\hline \multicolumn{2}{|c|}{$\begin{array}{l}\text { Billangan Ester } \\
\text { setcleh Asetilnsi }\end{array}$} & 115.5 & 150.3 & 172.4 & 143.7 & 146.5 & 159.7 & 137.6 \\
\hline \multicolumn{2}{|c|}{$\begin{array}{l}\text { Minyak Lemak \& } \\
\text { Minyak Keruing }\end{array}$} & negatif & nezatif & negatif & Degatif & negatif & Negaif & Negative \\
\hline \multicolumn{2}{|c|}{$\begin{array}{l}\text { Kelarutan dalam } \\
\text { Allohol } 95 \%\end{array}$} & $\begin{array}{l}\text { 1:1 jennih, } \\
\text { dist jemih }\end{array}$ & $\begin{array}{l}\text { 1:1 jemih, } \\
\text { dst jemih }\end{array}$ & $1: 3$ janilh & , dst jemin & $\begin{array}{l}\text { 1:1 jemihth } \\
\text { dot jemith }\end{array}$ & \multicolumn{2}{|c|}{1.3 jemilh, det jenilh } \\
\hline
\end{tabular}




\section{KESIMPULAN}

Pada penelitian ini didapat kondisi terbaik ekstraksi fluida $\mathrm{CO}_{2}$ superkritik minyak akar wangi dengan laju alir karbondioksida sebesar 5.5 liter/menit, tekanan ekstraktor $1750 \mathrm{psi}$ dan suhu ekstraktor $40^{\circ} \mathrm{C}$. Kadar total vetiverol yang tertinggi didapat $51.82 \%$ pada rafinat. Dari hasil yang didapat, tingginya tekanan dan rendahnya suhu berpengaruh terhadap perolehan ekstrak; penurunan rafinat; peningkatan nilai bobot jenis ekstrak dan rafinat; indeks bias ekstrak dan rafinat; putaran optik ekstrak dan rafinat; peningkatan viskositas ekstrak dan rafinat; peningkatan bilangan ester ekstrak, bilangan ester setelah asetilasi ekstrak, serta meningkatnya kadar total vetiverol. Sedangkan tingginya tekanan dan suhu berpengaruh terhadap peningkatan bilangan asam di rafinat serta intensitas warna biru pada rafinat, sedangkan tekanan rendah dan suhu yang tinggi menyebabkan peningkatan intensitas warna kuning pada rafinat serta rendahnya tekanan dan suhu menyebabkan jumlah rafinat yang dihasilkan semakin besar.

\section{UCAPAN TERIMA KASIH}

Penulis mengucapkan terima kasih kepada Dr. Ir. Meika Syahbana Rusli dan Puji Darsih Utami ST, Fakultas Teknologi Pertanian-IPB atas kerjasamanya sehinga penelitian dan penulisan artikel ini berjalan dengan baik.

\section{DAFTAR PUSTAKA}

1. Anonim. 2009, Pohon Industri Akar Wangi,http://e2ndycom.wordpress.com/2009/05/ 29/pohon-industri-minyak-atsiri/diakses pada 22 Juli 2014.

2. Arai, Y., Sako, T., dan Takebayashi, Y. 2002. Supercritical Fluids Molecular Interactions, Physical Properties, and New Applications. Springer, Heidelberg.

3. C.J Chang, K.L Chang, Y.L Chang, 2001, Effect of ethanol content on carbon dioxide extraction of polyphenol from tea, J. Food Compos, Anal. 14, pp. 75-82.

4. H. Wang, C. Chen, CJ. Chang, 2001. Carbon dioxide extraction of ginseng root hair oil and ginsenosides, Food Chem. 72, pp 505-509

5. Laili, K., Febria, R., Sumarno dan Winardi, S. 2003. Ekstraksi Eugenol dari Minyak Cengkeh Rakyat Menggunakan Fluida Karbondioksida Superkritis. Prosiding Seminar Nasional Teknik Kimia Indonesia, 2003. Yogyakarta.

6. Mukhopadhyay (Ed). 2000. Natural Extracts Using Supercritical Carbon Dioxide. CRC Press LLC, New York.

7. McHugh, M.A. dan Krukonis, V. J. 1994. Supercritical Fluid Extraction Principles and Practice. Second Edition. ButterworthHeinemann, Stoneham.

8. Rizvi, S.S.H. 1999. Supercritical Fluid Processing of Food and Biomaterials. Aspen Publisher, Inc., Gaithersburg.

10. SNI 06 2386, revisi SNI 06-2386-1991, revisi SNI 06-2386-1995, Minyak akar wangi, http://sisni.bsn.go.id/index.php?/sni main/sni/de tail_sni/7589. Diakses pada 22 Juli 2014

11. Sudarwati, I. 2011, Analisis Harga Pokok Produksi dan Penjualan Minyak Akar Wangi di Kab. Garut, Jawa Barat. URL: http://repository.ipb.ac.id /handle/123456789 152428. Diakses pada 22 Juli 2014.

12. Sulaswatty, A. 1998. Karakteristik Pemekatan Karotenoid Minyak Sawit dengan Teknik Fluida $\mathrm{CO}_{2}$ Superkritik. Disertasi. Program Studi Ilmu Pangan, Institut Pertanian Bogor, Bogor.

13. Sulaswatty dan Wuryaningsih. 2001. Teknologi Ekstraksi dan Pemurnian Minyak Atsiri sebagai Bahan Baku Flavor dan Fragrance. Prosiding Simposium Rempah Indonesia, Jakarta.

14. Talansier, E. Mara E.M.B, Paulo T.V.R, Delphine P.J, M, Angela. A.M, 2008), Supercritical fluid extraction of vetiver roots: A study of SFE kinetic, J.of Supercritical Fluids, 47, pp. 200-208.

15. Ya Ping Sun. 2002. Supercritical Fluid Technology in Materials Science and Engineering Syntheses, Properties and Applications. Marcel Dekker, Inc., New York. 